\title{
Physiology of individual late-run Fraser River sockeye salmon (Oncorhynchus nerka) sampled in the ocean correlates with fate during spawning migration
}

\author{
Steven J. Cooke, Scott G. Hinch, Glenn T. Crossin, David A. Patterson, \\ Karl K. English, J. Mark Shrimpton, Glen Van Der Kraak, and Anthony P. Farrell
}

\begin{abstract}
Beginning in 1995, segments of the late-run sockeye salmon (Oncorhynchus nerka) stocks from the Fraser River, British Columbia, have initiated upriver spawning migration up to 6 weeks earlier than historical records; and those fish have experienced high rates of en route mortality. We examined the correlations between physiological and energetic status prior to river entry with subsequent migratory performance of individual salmon using telemetry and noninvasive biopsies for Adams-Thompson-Shuswap (Adams) and Weaver-Harrison (W-H) stocks. Salmon that failed to reach the river were characterized by a tendency to have elevated levels of chronic and acute stress indicators. For one stock of fish (i.e., Adams) that entered the river, those that died before reaching spawning grounds were individuals with low gross somatic energy. Furthermore, females tended to have elevated plasma estradiol levels. When contrasting fish with different behaviours and fates, fish that did not hold in the estuary and subsequently died tended to have less energy than fish that held and reached spawning areas. Females from the former group also had higher 11ketotestosterone and estradiol levels relative to those from the later group. These data suggest that differences in physiological and energetic status may be associated with high en route mortality in late-run sockeye salmon.

Résumé : Depuis 1995, des portions des stocks à migration tardive de saumons rouges (Oncorhynchus nerka) du Fraser, Colombie-Britannique, commencent leur migration de reproduction vers l'amont jusqu'à six semaines avant la période normale du passé et elles subissent de forts taux de mortalité durant le trajet. Nous examinons les corrélations entre les statuts physiologique et énergétique avant l'entrée en rivière et la performance subséquente de la migration chez des saumons individuels des stocks Adams-Thompson-Shuswap (Adams) et Weaver-Harrison (W-H) à l'aide de la télémétrie et de biopsies non invasives. Les saumons qui n'atteignent pas la rivière ont tendance à avoir des niveaux élevés d'indicateurs de stress chronique et aigu. Chez l'un des stocks (c.-à-d., Adams) qui a pénétré dans la rivière, les poissons qui sont morts avant d'atteindre les sites de fraye étaient des individus possédant une faible énergie somatique brute. De plus, les femelles avaient tendance à avoir des concentrations plasmatiques élevées d'oestradiol. En comparant des poissons ayant des comportements et des sorts différents, nous trouvons que les poissons qui ne se sont pas maintenus dans l'estuaire et qui sont morts subséquemment avaient tendance à avoir moins d'énergie que les poissons qui se sont maintenus et qui ont atteint les sites de fraye; les femelles du premier groupe avaient aussi des concentrations plus élevées de 11-céto-testostérone et d'oestradiol que celles du second groupe. Ces données indiquent que les statuts physiologique et énergétique peuvent être associés à une forte mortalité durant le trajet chez le saumon rouge.
\end{abstract}

[Traduit par la Rédaction]

Received 1 April 2005. Accepted 20 February 2006. Published on the NRC Research Press Web site at http://cjfas.nrc.ca on 2 June 2006.

$\mathrm{J} 18634$

S.J. Cooke ${ }^{1,2}$ and G.T. Crossin. Centre for Applied Conservation Research, Department of Forest Sciences, The University of British Columbia, 2424 Main Mall, Vancouver, BC V6T 1Z4, Canada.

S.G. Hinch. Centre for Applied Conservation Research, Department of Forest Sciences, The University of British Columbia, 2424 Main Mall, Vancouver, BC V6T 1Z4, Canada, and Institute for Resources, Environment and Sustainability, The University of British Columbia, Vancouver, BC V6T 1Z4, Canada.

D.A. Patterson. Fisheries and Oceans Canada, Science Branch, Pacific Region, Cooperative Resource Management Institute, School of Resource and Environmental Management, Simon Fraser University, Burnaby, BC V5A 1S6, Canada

K.K. English. LGL Limited Environmental Research, 9768 Second Street, Sydney, BC V8L 3Y8, Canada.

J.M. Shrimpton. Department of Biology, University of Northern British Columbia, Prince George, BC V2N 4Z9, Canada.

G. Van Der Kraak. Department of Zoology, University of Guelph, Guelph, ON N1G 2W1, Canada.

A.P. Farrell. Faculty of Agricultural Sciences and Department of Zoology, The University of British Columbia, Vancouver, BC V6T 1Z4, Canada.

${ }^{1}$ Corresponding author(e-mail: Steven_Cooke@carleton.ca).

${ }^{2}$ Present address: Institute of Environmental Science and Department of Biology, Carleton University, 1125 Colonel By Drive, Ottawa, ON K1S 5B6, Canada. 


\section{Introduction}

In the Fraser River, British Columbia (B.C.), there are a number of economically, culturally, and ecologically important sockeye salmon (Oncorhynchus nerka) stocks. Therefore, it is not surprising that both fisheries managers and the broader public are concerned when large proportions of upriver-migrating sockeye salmon perish before reaching their spawning grounds. Mortality during spawning migration is a natural and expected outcome for a segment of any population and serves as a major selective force (Dingle 1980). Indeed, historic records of en route mortality for sockeye salmon are typically near $10 \%$, with much higher levels observed in years when environmental conditions make migration more difficult for fish (Gilhousen 1990; Macdonald 2000). To date, a number of environmental conditions such as elevated levels of water temperature, suspended sediment, and water discharge are known to make migration more difficult and have been associated with in-river mortality (Macdonald et al. 2000). When these conditions collectively exceed the tolerance and (or) capabilities of the fish, en route mortality can occur (Rand and Hinch 1998; Hinch and Bratty 2000).

Migration is regarded as one of the most energetically demanding and physiologically challenging phases of a fish's life history. It represents one of the most complex interplays between behaviour and physiology (McKeown 1984; Lucas and Baras 2001; Hinch et al. 2005). Individual migrants can vary in their physiological (Lee et al. 2003; Shrimpton et al. 2005) and energetic (Hinch and Rand 1998; Kinnison et al. 2001) status, perhaps because of environmental influences and also genetic disposition. Despite the large body of research evaluating salmonid migrations, we know little about what differentiates a successful migrant from one that dies while en route to the spawning grounds (Lucas and Baras 2001; Hinch et al. 2005; Cooke et al. 2006). Such information is particularly important in years when mortality rates are quite high.

When fisheries managers document high levels of migration mortality for several sequential years that cannot be explained solely by in-river environmental conditions, uncertainty puts stocks at risk of extinction and generates conflict among different fishing sectors. In recent years, the late-run sockeye salmon stocks in the Fraser River have been experiencing a pattern of persistently high levels of mortality during spawning migrations, as well as alterations in their migration behaviour (Cooke et al. 2004b; Lapointe et al. 2004). These late-run sockeye salmon stocks represent one of four stock complexes in the Fraser River watershed distinguished by the timing of freshwater entry and the location of spawning (Killick 1955; Woodey 1987). They arrive in August near the mouth of the Fraser River in the Strait of Georgia (Fig. 1), where they normally remain for 3-6 weeks prior to initiating upriver migration. However, since 1995, segments of the population have initiated upriver migration up to 6 weeks earlier and therefore have reduced or eliminated their historic estuarine delay behaviour (Cooke et al. 2004b; Lapointe et al. 2004). Early migration does not confer an earlier spawning date, but instead is associated with high mortality rates, which in some years exceeds $90 \%$ for several stocks (Cooke et al. 2004b; Lapointe et al. 2004).
The objective of the present study was to evaluate the correlations between physiological and energetic status prior to river entry with their subsequent migratory performance (failure or success) in an attempt to understand this high mortality phenomenon. We tested the hypothesis that physiological and energetic status varies with migration fate. We predicted that failed migrants may exhibit elevated levels of stress indicators, low somatic energy, and advanced levels of reproductive and osmoregulatory preparedness in the marine environment. These predictions are based on a number of proposed behavioural and mortality mechanisms discussed in Cooke et al. (2004b). The majority of these predictions are intuitive aside from the one dealing with osmoregulatory preparedness. Our rationale for that prediction is that fish with advanced osmoregulatory preparedness may initiate upriver mortality prematurely and thus face higher water temperatures en route (Wagner et al. 2005). To test our hypothesis, we contrasted successful and unsuccessful migrants during ( $i$ ) their coastal migration through to river entry and (ii) their upriver migration to terminal spawning grounds. We also contrasted individuals that exhibited different marine delaying behaviours to specifically determine why mortality is higher in fish that do not hold. Our efforts focused on trying to elucidate the potential mechanistic basis for the observed high levels of en route mortality for late-run sockeye salmon, recognizing that causation could only be concluded after subsequent manipulative experiments. Eventually, it is our hope to develop a suite of predictive physiological tools that would aid in the management and conservation of late-run sockeye salmon and other Pacific salmonids. To address our objectives, we intercepted sockeye salmon in the coastal ocean environment as they headed toward the Fraser River estuary where they would begin their upriver migration. Fish were implanted with radio transmitters to follow their subsequent migration behaviour and to determine their fate. These same individuals were also biopsied, which included drawing blood from the caudal vessels, removing some gill filament tips, and quantifying energetic status using a microwave energy meter (Cooke et al. 2005). Radio receiving systems were deployed throughout the Fraser River and to its tributaries over a distance of $\sim 500 \mathrm{~km}$.

\section{Materials and methods}

\section{Sampling strategy}

The present investigation was part of a larger telemetry study in which sockeye salmon $(N=559)$ were intercepted near the southern end of Johnstone Strait, B.C., Canada (Fig. 1), approximately $215 \mathrm{~km}$ from the mouth of the Fraser River (see English et al. 2004). We developed protocols to biopsy a portion $(N=301)$ of these sockeye salmon (Cooke et al. 2005). Fish were sampled without anaesthesia. Anaesthetics currently approved for use in fish should not be ingested by humans and because the fish were released to the ocean to resume their normal migration, the possibility existed that they might be subsequently caught by fishers or other animals and consumed. Our protocols, which were approved by The University of British Columbia Animal Care Committee, were validated in a parallel study, in which three independent assessments were used to demonstrate that it was possible to biopsy and tag sockeye salmon without causing 
Fig. 1. Map of study system inset within Canada and the Fraser River Watershed of British Columbia (B.C.). Fish were implanted with transmitters and biosampled in Johnstone Strait, a coastal area where fish begin to encounter estuarine conditions. Late-run sockeye salmon (Oncorhynchus nerka) typically delay in the Strait of Georgia for several weeks prior to entering the river. A radio telemetry receiver array was deployed at Mission, B.C., $85 \mathrm{~km}$ upriver from the mouth of the Fraser River to monitor entry. This analysis focused on late-run sockeye from the Weaver-Harrison (W-H) or Adams-Thompson-Shuswap stock groups.

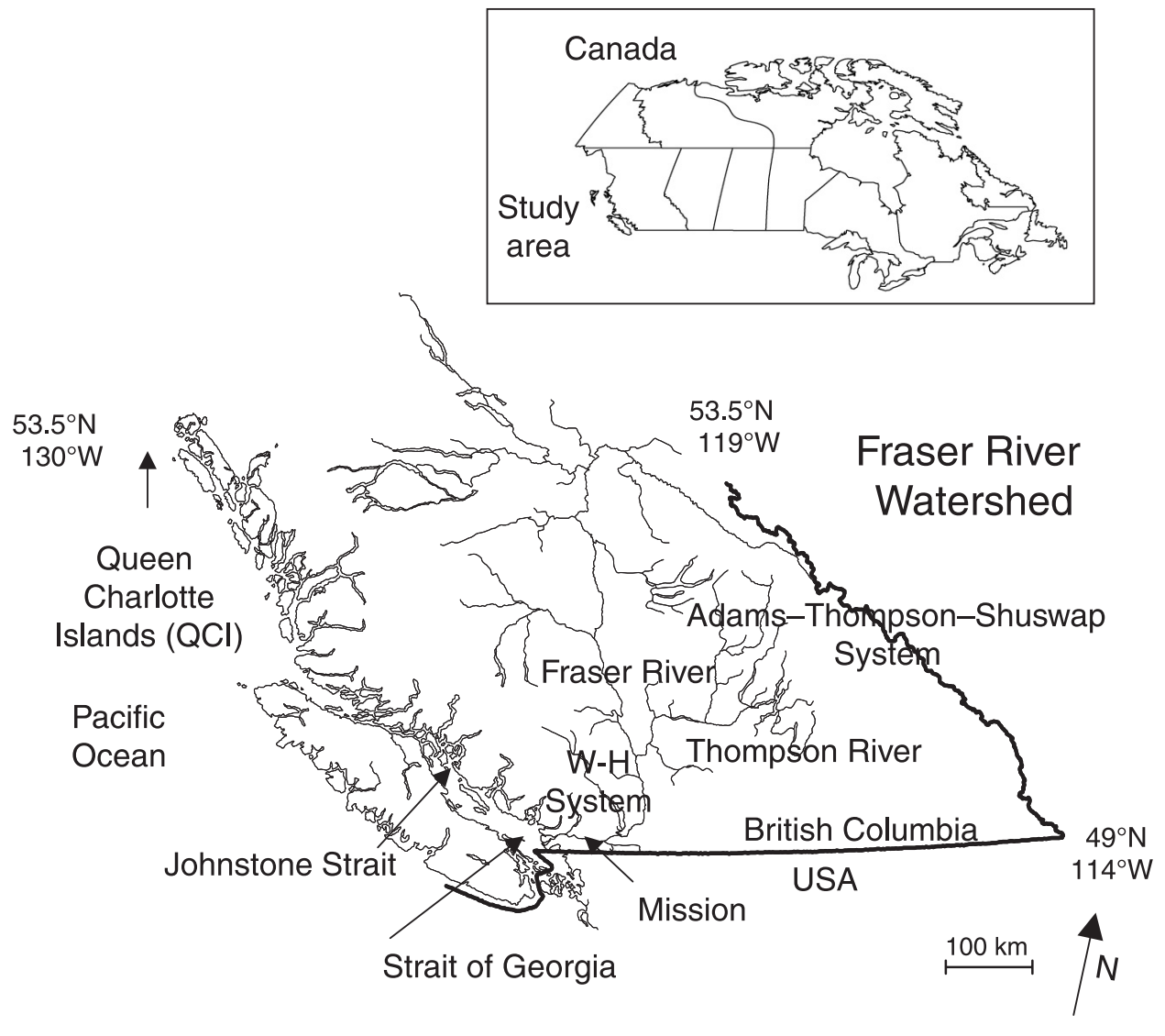

deleterious effects to behaviour or survival (Cooke et al. 2005).

Fish were collected using a large purse seine net deployed from a commercial fishing vessel, which also served as the platform for biopsy, radio-tagging, and fish release. Fish were sampled, tagged and released over a 3-week period between 11 August and 28 August 2003 at surface water temperatures of $10-13{ }^{\circ} \mathrm{C}$. Fish were first detected (i.e., arrival in the Fraser River) by two radio telemetry stations approximately $300 \mathrm{~km}$ from the release site at Mission, B.C., beyond the tidal boundary and $85 \mathrm{~km}$ upstream from the mouth of the river (Fig. 1). We defined an individual fish as successfully completing river entry once it was detected at the Mission telemetry station. Twelve additional telemetry stations were deployed at intervals along the mainstem Fraser and Thompson rivers and appropriate late-run terminal spawning grounds (e.g., Adams-Thompson-Shuswap (hereafter referred to as Adams), total distance of $400 \mathrm{~km}$ from Mission; WeaverHarrison (W-H), total distance of $85 \mathrm{~km}$ from Mission; Fig. 1). These receiving stations were equipped with up to three antennas and a data-logging radio receiver (SRX_400, Lotek Engineering Inc., Newmarket, Ontario), as detailed in English et al. (2004). Mobile tracking was also conducted by foot and boat. To encourage reporting of fish harvested by recreational anglers, commercial fishers, and First Nations fishers, we implemented a public awareness campaign and offered a small reward for information and transmitter return. Receivers were also used to scan for transmitters at three of the largest (by volume) fish processing plants in B.C. Reporting compliance was believed to be high (English et al. 2004), but any unreported harvesting would result in an overestimate of our mortality percentages.

\section{Synopsis of biopsy and tagging techniques}

Following capture, individual fish were netted from the purse (which remained in the water and was gathered at the side of the vessel) and placed in large flow-through totes on deck. Individuals were then removed from the tote, placed ventral-side-up in a padded V-shaped trough, and provided with a continuous supply of fresh, ambient seawater via a tube placed near the mouth. Fish were manually restrained for less than $3 \mathrm{~min}$, during which time fork length $(\mathrm{cm})$ was measured, tissues were biopsied, and a radio transmitter was inserted. The biopsy procedure involved $(a)$ removing a small piece $(0.5 \mathrm{~g})$ of the adipose fin for DNA stock identification, (b) removing one scale for ageing, (c) removing $3 \mathrm{~mL}$ of blood from the caudal vessel using a vacutainer syringe (1.5 inch, 21 gauge; Houston 1990) for assessing plasma chemistry, and $(d)$ removing $<4 \mathrm{~mm}$ from the tips of six to eight filaments $(0.03 \mathrm{~g})$ from the first gill arch (McCormick 1993) for assessing gill $\mathrm{Na}^{+} / \mathrm{K}^{+}$ATPase activity. Gill tissue and centrifuged plasma samples were stored on dry ice for 
several days until being transferred to a $-80{ }^{\circ} \mathrm{C}$ freezer, where they were held until analysis. A hand-held microwave energy meter (Distell Fish Fatmeter model 692, Distell Inc, West Lothian, Scotland, UK) was placed on the left side of the fish in two locations to quantify gross somatic energy levels (see Crossin and Hinch 2005). Radio transmitters, which measured $16 \mathrm{~mm}$ in diameter and $51 \mathrm{~mm}$ in length and weighed $16.1 \mathrm{~g}$ in air and $6.2 \mathrm{~g}$ in water (MCFT-3A, Lotek Inc., Newmarket, Ontario), were orally inserted into the stomach using a plastic applicator. Fish were returned to the holding tote to recover for $<1 \mathrm{~h}$ after this procedure. All fish in the tote were released as a group in an attempt to minimize predation by marine mammals.

\section{Assays}

The present analysis focused on fish from the two largest late-run sockeye stock groups; the $\mathrm{W}-\mathrm{H}$ and the Adams stocks (Fig. 1). Stock origin was ascribed to individual fish by a combination of DNA analyses (Beacham et al. 1995, 2004) and the recovery of radio transmitters at spawning grounds. Stock assignment through DNA analysis is a standard technique in fisheries management, and research for Fraser River sockeye salmon and overall has 96\% accuracy (T. Beacham, Fisheries and Oceans Canada, Pacific Biological Station, Hammond Bay Road, Nanaimo, B.C., V9R 5K6, personal communication). In our study, we focused on identifying late-run fish and then differentiating them into two primary stock groupings (i.e., $\mathrm{W}-\mathrm{H}$ and Adams), which are each composed of a number of differentiated populations. Thus, for our purposes DNA accuracy was likely higher than $96 \%$. Indeed, we observed no instances of incongruence between DNA analyses and arrivals at terminal spawning grounds for late-run sockeye supporting that idea. Furthermore, exclusion probabilities were uniformly high for fish that reached spawning grounds and fish that died en route for each of the two late-run stock complexes ( $t$ tests: $\mathrm{W}-\mathrm{H}$, $t=0.185, P=0.855$, mean \pm standard deviation (SD), survivors $0.97 \pm 0.09$, mortalities $0.98 \pm 0.06$; Adams, $t=-0.348$, $P=0.729$, survivors $0.91 \pm 0.12$, mortalities $0.90 \pm 0.12$ ). Of 559 sockeye sampled and released in the larger investigation, 188 fish were identified as late-run. We excluded six fish from other smaller late-run stocks, leaving data for 182 fish. The physiological analysis was restricted to 146 laterun fish, 117 of which had had tissue biopsies and energy measurements, while a further 29 fish had only energy measurements before release. The remaining fish were released with transmitters without being biosampled.

Plasma testosterone, 17 $\beta$-estradiol, and 11-ketotestosterone levels were measured by radioimmunoassay (McMaster et al. 1992) and used to assign gender. Plasma ion $\left(\mathrm{K}^{+}, \mathrm{Cl}^{-}\right.$, $\mathrm{Na}^{+}$), cortisol, lactate, glucose, and osmolality measurements followed the procedures described by Farrell et al. (2001). Gill tissue $\mathrm{Na}^{+} / \mathrm{K}^{+}$ATPase activity was determined with a kinetic assay (McCormick 1993) and expressed as $\mu \mathrm{mol}$ ADP.mg protein ${ }^{-1} \cdot \mathrm{h}^{-1}$. Detailed description of all assays presented here, including the interassay variability and quality control criteria, are provided in Farrell et al. (2001).

\section{Statistical analysis}

Multivariate analysis of variance (MANOVA) on $\log _{10^{-}}$ transformed data (McGarigal et al. 2000) revealed that stock-specific differences were only apparent for energetic and size information, so we pooled data from both $\mathrm{W}-\mathrm{H}$ and Adams for all other biological characteristics. Two-sample $t$ tests or their nonparametric equivalent (i.e., Mann-Whitney $U$ test when data were non-normal) were used to contrast the physiological and energetic status by fate. Fate was assessed during $(i)$ the river entry migration phase (i.e., excluding fishery removals, we compared fish that entered the Fraser River versus those that failed to do so) and (ii) the in-river migration phase (i.e., of fish that entered the river and were not harvested, we compared those that did not reach terminal spawning grounds in their natal subwatershed with those that were successful). Because each stock complex is composed of multiple populations, we used arrival in the natal subwatershed rather than arrival at actual spawning grounds as a proxy for success. "River entry" fish were those that were detected at the downstream telemetry receiving station at Mission, B.C. Reproductive hormone assays were restricted to fish that entered the river, so statistical analysis was only conducted for the in-river migration phase. For each hormone, sex was treated separately for statistical analysis.

All analyses were conduced using JMP 4.0 (SAS Institute Inc., Cary, North Carolina). Because of multiple comparisons, we conducted simultaneous Bonferroni corrections (Zar 1996). We selected an initial $\alpha$ of 0.10 so that we did not end up with overly conservative $\alpha$ levels after Bonferroni corrections (see Cabin and Mitchell 2000) and to increase statistical power (i.e., reduce type II errors; Peterman 1990). For analyses, we present corrected and uncorrected $\alpha$ levels (see Tables 1, 2, and 3) to enable the reader to perform their own assessment as to which significance criteria to observe (as per Cabin and Mitchell 2000). As a secondary assessment of the role of conducting multiple comparisons, binomial likelihood tests were completed for each analysis to determine if the number of tests that were significant was more than expected by chance $(P=0.10)$. Retrospective power analyses were conducted $(i)$ using the observed effect size and variance and (ii) using a predetermined effect size $(5 \%)$ and the observed variance (Thomas 1997). Power analyses were conducted to aid in the interpretation of data and are presented in concert with $P$ values in tabular form.

\section{Results}

\section{River entry migration phase}

Of the 182 late-run sockeye salmon released that avoided the ocean fishery (i.e., 181, one was harvested), 67 (37\%) individuals failed to enter the Fraser River. Sockeye salmon that failed to enter the Fraser River exhibited a number of physiological differences relative to those that were successful. Indicators of chronic and acute stress including plasma glucose $(P=0.076)$, plasma lactate $(P<0.001)$, and plasma cortisol $(P=0.090)$ had been higher in fish that failed to enter the river (Table 1$)$. Plasma $\mathrm{Na}^{+}(P=0.009)$ had been higher in sockeye salmon that entered the river, whereas plasma osmolality $(P=0.002)$ had been higher in fish that did not (Table 1). No other significant differences were noted despite there being reasonable power for most analyses (Table 1). 
Table 1. Comparison of biological variables between late-run sockeye salmon (Oncorhynchus nerka) that died before entering the Fraser River at Mission, B.C., with those that survived to Mission, B.C.

\begin{tabular}{|c|c|c|c|c|c|c|c|c|}
\hline Variables & $\begin{array}{l}\text { Died prior to } \\
\text { river entry }\end{array}$ & $N$ & $\begin{array}{l}\text { Survived to } \\
\text { river entry }\end{array}$ & $N$ & $\begin{array}{l}\text { Test } \\
\text { statistic }\end{array}$ & $P$ value & $\begin{array}{l}\text { Observed } \\
\text { power }\end{array}$ & $\begin{array}{l}\text { Effect size } \\
\text { power }\end{array}$ \\
\hline \multicolumn{9}{|l|}{ Nose fork length $(\mathrm{cm})$} \\
\hline W-H & $60.6 \pm 0.5$ & 27 & $60.9 \pm 0.5$ & 31 & $t,-0.52$ & 0.605 & 0.144 & 1.000 \\
\hline \multicolumn{9}{|l|}{ Gross somatic energy $\left(\mathrm{MJ} \cdot \mathrm{kg}^{-1}\right)$} \\
\hline $\mathrm{W}-\mathrm{H}$ & $8.27 \pm 0.21$ & 26 & $7.85 \pm 0.18$ & 27 & $t, 1.55$ & 0.126 & 0.458 & 0.419 \\
\hline \multicolumn{9}{|l|}{ Ions $\left(\mathrm{mmol} \cdot \mathrm{L}^{-1}\right)$} \\
\hline $\mathrm{Na}^{+}$ & $182.5 \pm 1.2$ & 48 & $186.6 \pm 0.9$ & 72 & $t,-2.65$ & 0.009 & 0.839 & 1.000 \\
\hline $\mathrm{K}^{+}$ & $1.26 \pm 0.15$ & 48 & $1.53 \pm 0.12$ & 72 & $t,-1.33$ & 0.186 & 0.376 & 0.981 \\
\hline $\mathrm{Cl}^{-}$ & $147.4 \pm 0.6$ & 46 & $148.4 \pm 0.6$ & 69 & $t,-1.17$ & 0.245 & 0.317 & 1.000 \\
\hline Osmolality $\left(\mathrm{mosmol} \cdot \mathrm{kg}^{-1}\right)$ & $354.9 \pm 2.3$ & 48 & $345.8 \pm 1.8$ & 73 & $t, 3.14$ & 0.002 & 0.931 & 1.000 \\
\hline Cortisol $\left(\mathrm{ng} \cdot \mathrm{mL}^{-1}\right)$ & $562.6 \pm 56.3$ & 47 & $458.2 \pm 32.9$ & 73 & $\mathrm{t}, 1.71$ & 0.090 & 0.523 & 0.129 \\
\hline
\end{tabular}

Note: Fishery losses from the ocean were excluded from analyses. Multiple analysis of variance revealed that stock differences were only significant for energetics and size variables, so for all other analyses we pooled fish from both the Weaver-Harrison (W-H) and Adams-Thompson-Shuswap (Adams) stock groups. All other analyses represent all late-run sockeye that passed Mission. Analyses were conducted using two-sample $t$ tests when data were normal and met the homogeneity of variance assumption. Italicized statistical output indicates significant differences at $\alpha=0.10$. Because we conducted multiple comparisons, Bonferroni corrections were applied and significant values based on this criterion (i.e., $\alpha=0.01$ ) were bolded. A binomial likelihood test revealed that the number of tests that were significant was greater than expected by chance $(P=0.004)$. Retrospective power analyses $(1-\beta)$ are reported in two forms. Observed power was calculated using the observed effect size and variance. Effect size power was calculated using a predetermined effect size of $5 \%$ and the observed variance.

\section{Upriver migration phase}

Excluding in-river fishery removals $(N=6), 108$ late-run sockeye salmon passed the lower river telemetry station and initiated upriver migration (Table 1). Of these fish, 39 (36.1\% for both stock groups, $36.6 \%$ for $\mathrm{W}-\mathrm{H}$ and $35.9 \%$ for Adams) failed to reach their natal spawning ground and were considered en route mortalities. Overall, 69 late-run sockeye $(63.9 \%$ of fish that entered the river and avoided harvest) were considered successful migrants. Of the 182 late-run sockeye tagged in the Johnstone Strait (excluding the seven harvested fish), $38.1 \%$ reached their natal subwatershed. Fewer physiological variables were associated with upriver fate than with the previous river entry migration phase. Gross somatic energy was lower $(P=0.078)$ in fish that failed to reach spawning grounds from the Adams stock but not for $\mathrm{W}-\mathrm{H}$ (Table 2). For females, estradiol hormone titres was higher $(P=0.097)$ in fish that died en route relative to successful migrants (Table 2). No other physiological variables differed statistically with fate, although statistical power was generally low for most endocrine and stress indicators (i.e., $1-\beta<0.70$ ), suggesting that larger sample sizes were required to detect a difference.

\section{Holding behaviour and fate}

Complimentary analyses focusing on timing-related issues revealed that significant differences in physiology and energetics were associated with different estuarine holding behaviours (S.J. Cooke, unpublished data). We thus grouped fish based on duration of estuarine holding using the 25th and 75th percentiles to yield one group that held for 2 days or less and another group that held for greater than 13 days.
Mortality rates clearly differed for these two holding behaviours (Fig. 2). Owing to sample size limitations, we focused additional analyses on the two groups of primary interest that comprised the majority of the fish: the fish that did not hold and died en route and the fish that did hold and successfully reached spawning grounds (i.e., we excluded fish that held and died en route and those that did not hold and reached terminal spawning grounds; Fig. 2). Gross somatic energy had been lower in fish that did not hold and failed to reach spawning grounds, but only significantly for the Adams stock group $(P=0.035$; Table 3$)$. For females, both $17 \beta$ estradiol $(P=0.019)$ and 11-ketotestosterone $(P=0.038)$ hormone titres had been significantly higher in fish that did not hold and died en route compared with fish that held and were successful migrants (Table 3). No other physiological variables were determined to be associated with differences in holding behaviour and subsequent fate. However, statistical power was generally low for most endocrine and stress indicators (i.e., $1-\beta<0.70$ ), as noted for the in-river phase.

\section{Discussion}

A segment of late-run Fraser River sockeye salmon populations have altered their migratory behaviour in recent years, initiating their upriver migrations without exhibiting a characteristic marine holding pattern (Cooke et al. 2004b; Lapointe et al. 2004). Fish that do not exhibit this holding behaviour experience exceptionally high rates of mortality (Cooke et al. 2004b; Lapointe et al. 2004). We found a number of factors that were associated with mortality at different phases of the spawning migration. We discuss these in light 
Table 2. Comparison of biological variables between late-run sockeye salmon (Oncorhynchus nerka) that entered the river and were detected at Mission, B.C., and either died en route to spawning grounds or arrived at terminal spawning grounds.

\begin{tabular}{|c|c|c|c|c|c|c|c|c|}
\hline Variables & $\begin{array}{l}\text { In river en } \\
\text { route loss }\end{array}$ & $N$ & $\begin{array}{l}\text { Reached natal } \\
\text { subwatershed }\end{array}$ & $N$ & $\begin{array}{l}\text { Test } \\
\text { statistic }\end{array}$ & $P$ value & $\begin{array}{l}\text { Observed } \\
\text { power }\end{array}$ & $\begin{array}{l}\text { Effect size } \\
\text { power }\end{array}$ \\
\hline \multicolumn{9}{|l|}{ Nose fork length $(\mathrm{cm})$} \\
\hline $\mathrm{W}-\mathrm{H}$ & $60.8 \pm 0.9$ & 11 & $61.0 \pm 0.5$ & 19 & $t,-0.20$ & 0.846 & 0.106 & 0.949 \\
\hline Adams & $61.7 \pm 0.4$ & 28 & $61.0 \pm 0.3$ & 50 & $t, 1.19$ & 0.238 & 0.323 & 1.000 \\
\hline \multicolumn{9}{|c|}{ Gross somatic energy $\left(\mathrm{MJ} \cdot \mathrm{kg}^{-1}\right)$} \\
\hline $\mathrm{W}-\mathrm{H}$ & $7.93 \pm 0.29$ & 9 & $7.91 \pm 0.22$ & 17 & $t, 0.06$ & 0.953 & 0.101 & 0.291 \\
\hline \multicolumn{9}{|l|}{ Ions $\left(\mathrm{mmol} \cdot \mathrm{L}^{-1}\right)$} \\
\hline $\mathrm{Na}^{+}$ & $186.4 \pm 1.6$ & 24 & $186.0 \pm 1.2$ & 42 & $t, 0.19$ & 0.849 & 0.106 & 0.998 \\
\hline $\mathrm{K}^{+}$ & $1.54 \pm 0.17$ & 24 & $1.56 \pm 0.18$ & 42 & $t,-0.82$ & 0.935 & 0.101 & 0.114 \\
\hline $\mathrm{Cl}^{-}$ & $148.7 \pm 1.2$ & 24 & $148.5 \pm 0.7$ & 39 & $t, 0.19$ & 0.852 & 0.106 & 1.000 \\
\hline Osmolality $\left(\mathrm{mosmol} \cdot \mathrm{kg}^{-1}\right)$ & $346.3 \pm 3.4$ & 25 & $345.8 \pm 2.3$ & 42 & $t, 0.13$ & 0.897 & 0.103 & 0.997 \\
\hline Cortisol $\left(\mathrm{ng} \cdot \mathrm{mL}^{-1}\right)$ & $495.7 \pm 64.0$ & 25 & $435.7 \pm 40.8$ & 42 & $t, 0.83$ & 0.409 & 0.212 & 0.118 \\
\hline \multicolumn{9}{|l|}{ Testosterone $\left(\mathrm{pg} \cdot \mathrm{mL}^{-1}\right)$} \\
\hline Male & $10113 \pm 814$ & 10 & $10623 \pm 490$ & 16 & $t,-0.57$ & 0.573 & 0.152 & 0.157 \\
\hline Female & $12301 \pm 1049$ & 15 & $11859 \pm 481$ & 26 & $t, 0.44$ & 0.665 & 0.131 & 0.161 \\
\hline \multicolumn{9}{|l|}{ 11-Ketotestosterone $\left(\mathrm{pg} \cdot \mathrm{mL}^{-1}\right)$} \\
\hline Male & $4998.8 \pm 448.6$ & 10 & $5412.8 \pm 305.9$ & 16 & $t,-0.79$ & 0.437 & 0.198 & 0.142 \\
\hline Female & $966.5 \pm 80.9$ & 15 & $874.1 \pm 37.5$ & 26 & $t, 1.18$ & 0.246 & 0.315 & 0.159 \\
\hline \multicolumn{9}{|l|}{$17 \beta$-Estradiol $\left(\mathrm{pg} \cdot \mathrm{mL}^{-1}\right)$} \\
\hline Male & $415.4 \pm 96.7$ & 10 & $364.1 \pm 27.5$ & 16 & $t, 0.62$ & 0.544 & 0.160 & 0.109 \\
\hline Female & $5288 \pm 607$ & 15 & $4313 \pm 262$ & 26 & $t, 1.70$ & 0.097 & 0.510 & 0.129 \\
\hline
\end{tabular}

Note: Fishery losses from the river were excluded from analyses. Multiple analysis of variance revealed that stock differences were only significant for energetics and size variables, so for all other analyses we pooled fish from both the Weaver-Harrison (W-H) and Adams-Thompson-Shuswap (Adams) stock groups. All other analyses represent all late-run sockeye that passed Mission. Reproductive hormones were analyzed by gender. Analyses were conducted using two-sample $t$ tests when data were normal and met the homogeneity of variance assumption. Italicized statistical output indicates significant differences at $\alpha=0.10$. Because we conducted multiple comparisons, Bonferroni corrections were applied and significant values based on this criterion (i.e., $\alpha=0.008$ ) would have been bolded. A binomial likelihood test revealed that the number of tests that were significant was fewer than expected by chance $(P=0.549)$. Retrospective power analyses $(1-\beta)$ are reported in two forms. Observed power was calculated using the observed effect size and variance. Effect size power was calculated using a predetermined effect size of $5 \%$ and the observed variance.

of other information that we have learned about late-run sockeye salmon migration biology obtained from parallel studies.

\section{River entry phase}

Approximately $30 \%$ of fish tagged failed to reach Mission, B.C., a point $85 \mathrm{~km}$ upstream from the river mouth where tidal influence and salt water were no longer present. Based on that finding alone, it is clear that there is significant en route mortality in the coastal environment and the tidally influenced section of the river, not just in the upriver areas. Fish that failed to reach Mission had been more physiologically stressed than fish that did, as revealed by stress indicators (e.g., plasma glucose, lactate, and cortisol). These elevated stress levels are suggestive of elevated energy expenditures (Barton and Schreck 1987) and suppression of reproductive hormones (Kubokawa et al. 2001; Carruth et al. 2002) and hence fitness (Schreck et al. 2001). They also can be responsible for, and immediately precede, mortality (Wood et al. 1983; Farrell et al. 2000).

There is no doubt that capturing fish in a purse seine and holding them on board a research vessel imparted stress.
However, it is unlikely that the mortality levels we observed are solely attributable to our interventions (Cooke et al. 2005). For example, when fish were just tagged and not biopsied, there was no difference in either their subsequent mortality rate or their rates of travel from the release site to the river relative to tagged and biopsied individuals (Cooke et al. 2005). Although this is not a direct test of capturerelated stress, it does suggest that the stress levels we observed are reflective of a biologically meaningful variation in precapture condition that, as we found, was predictive of en route mortality. In a complimentary study, Cooke et al. (2006) determined that the order of fish sampling-tagging did not influence the fate of summer-run sockeye salmon. Furthermore, we have held ocean-captured sockeye salmon in saltwater laboratory settings to obtain baseline cortisol values (Hinch et al. 2005; A.P. Farrell, unpublished data; e.g., mean \pm standard error (SE) plasma cortisol, $354 \pm$ $95 \mathrm{ng} \cdot \mathrm{mL}^{-1}$ ), and they were comparable with values observed in the current study (e.g., overall mean \pm SE plasma cortisol, $\left.435 \pm 41 \mathrm{ng} \cdot \mathrm{mL}^{-1}\right)$. Increases in plasma cortisol typically reach peak levels $\sim 1 \mathrm{~h}$ after the initial stressor, whereas plasma glucose would be expected to peak about an 
Fig. 2. Fate of late-run sockeye salmon (Oncorhynchus nerka) in the Fraser River, British Columbia, relative to holding behaviour. Data include late-run fish that entered the Fraser River (excluding fishery removals) with either less than 2 days of holding (no hold) or more than 13 days of holding (hold). Hatched areas indicate successful migrants, whereas open areas represent failed migrants. Numbers indicate the number of fish in each category. The arrow denotes the two primary outcomes for fish (i.e., do not hold in Strait of Georgia and die en route to spawning grounds or hold in Strait of Georgia and successfully reach spawning grounds).

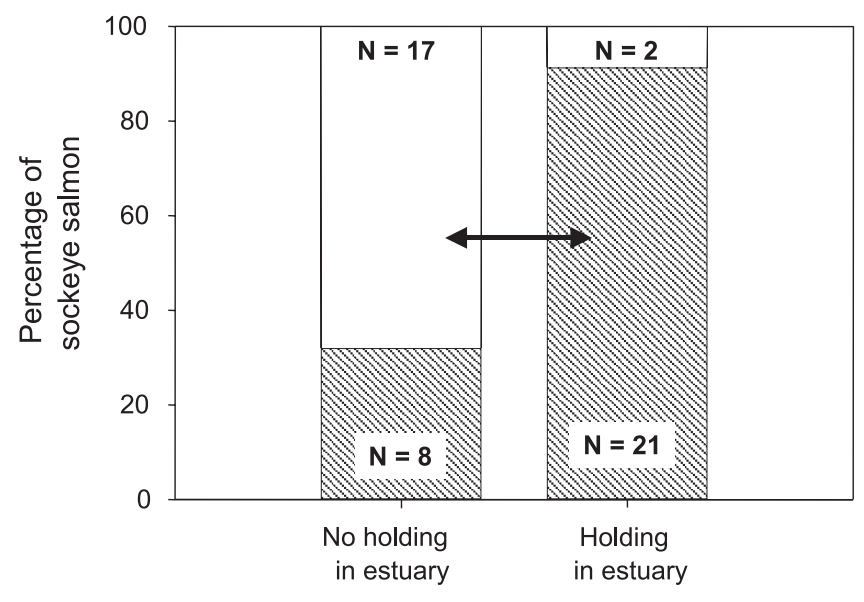

Holding behaviour

hour after that (Milligan 1996; Mommsen et al. 1999; Barton 2002). Fish captured in the seine net were immediately transferred to an onboard tank (as described in Materials and methods) for temporary holding and sampled within $30 \mathrm{~min}$ of capture, so it is unlikely that the cortisol or glucose values obtained reflect differential handling or holding periods. Nonetheless, individuals varied widely in their cortisol levels, suggesting that either fish were experiencing a background level of chronic stress prior to being captured or that the elevation of plasma cortisol during spawning migration of Pacific salmonids is normal (Carruth et al. 2000, 2002). Premature elevation of cortisol could lead to senescence and eventual mortality of salmonids and typically does not occur until after fish have initiated upriver migrations (Carruth et al. 2002).

In addition to the stress indicators discussed above, the plasma $\mathrm{Na}^{+}$concentrations were lower in fish that failed to reach the river, whereas plasma osmolality was higher in failed migrants. Hinch et al. (2005) report resting plasma $\mathrm{Na}^{+}\left(\right.$mean $\left.\pm \mathrm{SE}, 185 \pm 3 \mathrm{mmol} \cdot \mathrm{L}^{-1}\right)$ and osmolality (mean \pm $\mathrm{SE}, 334 \pm 17 \mathrm{mosmol} \cdot \mathrm{kg}^{-1}$ ) values for ocean-caught sockeye salmon held in saltwater. The resting plasma $\mathrm{Na}^{+}$value from Hinch et al. (2005) is comparable with the value for fish that successfully reached the river (mean \pm SE, 186.6 \pm $\left.0.9 \mathrm{mmol} \cdot \mathrm{L}^{-1}\right)$ and higher than those that died prior to river entry $\left(\right.$ mean $\left.\pm \mathrm{SE}, 182.5 \pm 1.2 \mathrm{mmol} \cdot \mathrm{L}^{-1}\right)$. In contrast, the resting plasma osmolality value from Hinch et al. (2005) was lower than both successful (mean \pm SE, $345.8 \pm$ $1.8 \mathrm{mosmol} \cdot \mathrm{kg}^{-1}$ ) and especially failed (mean $\pm \mathrm{SE}, 354.9 \pm$ $2.3 \mathrm{mosmol} \cdot \mathrm{kg}^{-1}$ ) river entrants. Generally, when fish experience stress in the marine environment, both plasma $\mathrm{Na}^{+}$concentrations and plasma osmolality tend to increase by $\sim 10$ units (i.e., either $\mathrm{mmol} \cdot \mathrm{L}^{-1}$ or mosmol $\cdot \mathrm{kg}^{-1}$; Barton et al. 2002). Thus the lower $\mathrm{Na}^{+}$and higher osmolality values for failed migrants are biologically relevant but in contradiction, suggesting that the osmoregulatory apparatus and therefore hydromineral balance of failed migrants may be compromised, potentially affecting the salt-to-freshwater transition (Clarke and Hirano 1995). We have documented that variable levels of gill $\mathrm{Na}^{+} / \mathrm{K}^{+}$ATPase are characteristic of early entry fish (S.J. Cooke, unpublished data), lending support to the idea that the level of osmoregulatory preparedness for fresh water may influence early entry and subsequent mortality. In brown trout (Salmo trutta), osmoregulatory status has been correlated with the initiation of migration behaviour (Aarestrup et al. 2000; Nielsen et al. 2004). An alternative explanation to the contradiction observed between $\mathrm{Na}^{+}$and osmolality is that other solutes have affected osmotic pressure, but were not measured in our study (e.g., proteins, sugars, and other ions).

\section{In-river phase}

Overall en route (fishery-independent) mortality rates for late-run sockeye between Mission and the terminal spawning grounds were approximately $36 \%$ for telemetered fish. When mortality rates for these telemetered salmon were abundance-weighted to account for differences in total late-run river abundance at time of tagging and river entry, en route mortality was $42 \%$ (English et al. 2004). However, late-run mortality estimates generated from hydroacoustic counts (Hedgepeth et al. 2000) at Mission (M. Lapointe, Pacific Salmon Commission, Suite 600, 1155 Robson Street, Vancouver, BC V6E 1B5, unpublished data) and arrivals at terminal spawning grounds (minus fishery removals) were much higher in 2003 overall (i.e., $65 \%$ ), but this may reflect the fact that we did not telemeter fish in the first $32 \%$ of the late-run migration, which were expected to have had even higher mortality. These data provide additional support that our tagging and biopsy technique did not contribute to abnormally high mortality and was reflective of the condition of the fish during the later periods (i.e., after initial $32 \%$ of run) of the migration.

The physiological and energetic condition of sockeye salmon intercepted in Johnstone Strait provided limited insight into in-river mortality. Adams late-run sockeye that reached their spawning grounds tended to have a higher somatic energy at time of sampling compared with those that died en route. However, the same trend was not apparent for the $\mathrm{W}-\mathrm{H}$ fish. Furthermore, the $P$ value was 0.078 and thus exceeds the Bonferroni-corrected $P$ value of 0.008 . Somatic energy reserves are crucial for powering upriver swimming activity (Brett 1995; Rand and Hinch 1998), for egg production (Kinnison et al. 2001, 2003; Patterson et al. 2004), for secondary sexual character development (Hendry and Berg 1999), and for reproductive behaviours (Healey et al. 2003), and low somatic energy can lead to premature energy depletion, en route mortality (Rand and Hinch 1998), and reduced reproductive investment (Hendry and Berg 1999; Kinnison et al. 2001, 2003). Crossin et al. (2004) reported substantial stock-specific differences in somatic energy between fish from the $\mathrm{W}-\mathrm{H}$ and those from Adams, with the former having lower energy densities than the latter. The fact that we only noted differences in somatic energy among survivors 
Table 3. Planned contrast of biological variables for late-run sockeye salmon (Oncorhynchus nerka) that entered the river and were detected at Mission, B.C., and either died en route to spawning grounds after not holding in the Strait of Georgia or arrived at terminal spawning grounds after holding in the Strait of Georgia.

\begin{tabular}{|c|c|c|c|c|c|c|c|c|}
\hline Variables & $\begin{array}{l}\text { En route loss } \\
\text { of no-hold fish }\end{array}$ & $N$ & $\begin{array}{l}\text { Fish that reached } \\
\text { natal subwatersheds } \\
\text { after holding }\end{array}$ & $N$ & $\begin{array}{l}\text { Test } \\
\text { statistic }\end{array}$ & $P$ value & $\begin{array}{l}\text { Observed } \\
\text { power }\end{array}$ & $\begin{array}{l}\text { Effect size } \\
\text { power }\end{array}$ \\
\hline \multicolumn{9}{|l|}{ Nose fork length $(\mathrm{cm})$} \\
\hline Adams & $61.4 \pm 0.8$ & 12 & $60.7 \pm 0.6$ & 17 & $t, 0.65$ & 0.524 & 0.166 & 0.999 \\
\hline \multicolumn{9}{|l|}{ Gross somatic energy $\left(\mathrm{MJ} \cdot \mathrm{kg}^{-1}\right)$} \\
\hline \multicolumn{9}{|l|}{ Plasma } \\
\hline \multicolumn{9}{|l|}{ Ions $\left(\mathrm{mmol} \cdot \mathrm{L}^{-1}\right)$} \\
\hline $\mathrm{Na}^{+}$ & $186.6 \pm 2.3$ & 11 & $189.9 \pm 2.4$ & 15 & $t,-0.96$ & 0.348 & 0.242 & 0.996 \\
\hline $\mathrm{K}^{+}$ & $1.43 \pm 0.26$ & 11 & $1.58 \pm 0.27$ & 15 & $t,-0.39$ & 0.701 & 0.124 & 0.114 \\
\hline $\mathrm{Cl}^{-}$ & $146.8 \pm 1.8$ & 11 & $149.5 \pm 1.4$ & 13 & $t,-1.18$ & 0.249 & 0.312 & 0.999 \\
\hline Osmolality (mosmol $\cdot \mathrm{kg}^{-1}$ ) & $346.7 \pm 4.7$ & 11 & $345.8 \pm 4.1$ & 15 & $t, 0.14$ & 0.889 & 0.103 & 0.998 \\
\hline $\begin{array}{l}\mathrm{Na}^{+} / \mathrm{K}^{+} \text {ATPase }(\mu \mathrm{mol} \text { ADP.mg } \\
\left.\quad \text { protein }^{-1} \cdot \mathrm{h}^{-1}\right)\end{array}$ & $2.32 \pm 0.31$ & 11 & $2.65 \pm 0.17$ & 14 & $U,-0.97$ & 0.344 & 0.245 & 0.142 \\
\hline \multicolumn{9}{|l|}{ Testosterone $\left(\mathrm{pg} \cdot \mathrm{mL}^{-1}\right)$} \\
\hline Male & $11567 \pm 1211$ & 5 & $10229 \pm 1308$ & 4 & $t, 0.747$ & 0.480 & 0.176 & 0.151 \\
\hline Female & $13566 \pm 2066$ & 6 & $10935 \pm 472$ & 11 & $t, 1.63$ & 0.125 & 0.464 & 0.148 \\
\hline \multicolumn{9}{|l|}{ 11-Ketotestosterone $\left(\mathrm{pg} \cdot \mathrm{mL}^{-1}\right)$} \\
\hline Male & $5658.5 \pm 786.9$ & 5 & $4785.5 \pm 562.6$ & 4 & $t, 0.86$ & 0.420 & 0.200 & 0.147 \\
\hline Female & $1016.1 \pm 154.3$ & 6 & $750.7 \pm 26.1$ & 11 & $t, 2.28$ & 0.038 & 0.702 & 0.145 \\
\hline \multicolumn{9}{|l|}{$17 \beta$-Estradiol $\left(\mathrm{pg} \cdot \mathrm{mL}^{-1}\right)$} \\
\hline Male & $517.9 \pm 169.8$ & 5 & $395.1 \pm 41.3$ & 4 & $t, 0.63$ & 0.551 & 0.154 & 1.000 \\
\hline Female & $6029 \pm 1083$ & 6 & $3868 \pm 659$ & 11 & $t, 2.62$ & 0.019 & 0.804 & 0.123 \\
\hline
\end{tabular}

Note: Fishery losses from the river were excluded from analyses. Multiple analysis of variance revealed that stock differences were only significant for energetics and size variables, so for all other analyses we pooled fish from both the Weaver-Harrison (W-H) and Adams-Thompson-Shuswap (Adams) stock groups. All other analyses represent all late-run sockeye that passed Mission. Reproductive hormones were analyzed by gender. Analyses were conducted using two-sample $t$ tests when data were normal and met the homogeneity of variance assumption. Italicized statistical output indicates significant differences at $\alpha=0.10$. Because we conducted multiple comparisons, Bonferroni corrections were applied and significant values based on this criterion (i.e., $\alpha=0.008$ ) would have been bolded. A binomial likelihood test revealed that the number of tests that were significant was fewer than expected by chance $(P=0.266)$. Retrospective power analyses $(1-\beta)$ are reported in two forms. Observed power was calculated using the observed effect size and variance. Effect size power was calculated using a predetermined effect size of $5 \%$ and the observed variance.

and failed migrants for the Adams group may reflect the fact that $\mathrm{W}-\mathrm{H}$ fish are under weaker energetic selection because of a less arduous migration (W-H fish make a $161 \mathrm{~km}$ river migration and gain $\sim 10 \mathrm{~m}$ in vertical elevation; Adams fish make a $485 \mathrm{~km}$ river migration and gain $\sim 366 \mathrm{~m}$ vertical elevation; Crossin et al. 2004).

In this study, females that died en route also tended to have elevated levels of plasma estradiol (marginally significant at $P<0.10$; i.e., $P=0.097$ ), and although none of the other hormone titres in females (i.e., 11-ketotestosterone and testosterone) were significantly different between failed and successful migrants, all three hormone titres were elevated in unsuccessful males. Since these hormones normally increase progressively as salmon mature reproductively (Truscott et al. 1986; Leonard et al. 2002), we interpret these data as indicating that unsuccessful migrants may have been in an advanced state of reproductive development (Robertson 1961; Robertson et al. 1961). Furthermore, given that reproductive development in salmon is associated with a loss in body mass and energy stores (Crossin et al. 2004), the elevated reproductive hormone titres and lower energy reserves of failed migrants may themselves be related and potentially indicate early senescence.

\section{Holding behaviour and fate}

Alterations in late-run sockeye salmon behaviour have been correlated with high levels of en route mortality (Cooke et al. 2004b; English et al. 2004). Many of our late-run sockeye spent less than 2 days holding in the Strait of Georgia, whereas others held for 2-3 weeks. We therefore pooled these fish accordingly into groups that essentially had no marine holding and those that had at least 2 weeks of marine holding. It turned out that the majority (79\%) of our fish fell into one of two groupings: those that did not hold and died en route and those that held and successfully reached spawning grounds. Interestingly, when these two subgroups were contrasted, many of the same physiological differences emerged as we found for the in-river analysis, unlike work on summer-run sockeye (Cooke et al. 2006). Specifically, somatic energy levels tended to be higher in Adams sockeye 
Fig. 3. Schematic representation of the behaviour and fate of late-run Fraser River sockeye salmon (Oncorhynchus nerka) with associated physiological and energetic profiles. The schematic is ordered from bottom to top reflecting the upstream progression of fish towards terminal spawning grounds. Detailed map of locations can be found in Fig. 1. Also, the physiological and energetic characteristics of fish in each category are provided to the left for successful migrants and to the right for en route mortalities. (A) Fish tagged in Johnstone Strait that achieve successful river entry. (B) Fish tagged in Johnstone Strait that fail to enter the river. Of the fish in A, some of those fish continue onwards and successfully reach spawning grounds (C) or die en route (D). The two primary outcomes for late-run sockeye (i.e., F, do not hold in Strait of Georgia and die en route to spawning grounds; or E, hold in Strait of Georgia and successfully reach spawning grounds) correspond to Fig. 2 and Table 3. The asterisk indicates that gross somatic energy is only significant $(\alpha=0.10)$ for fish from the Adams-Thompson-Shuswap (Adams) group.

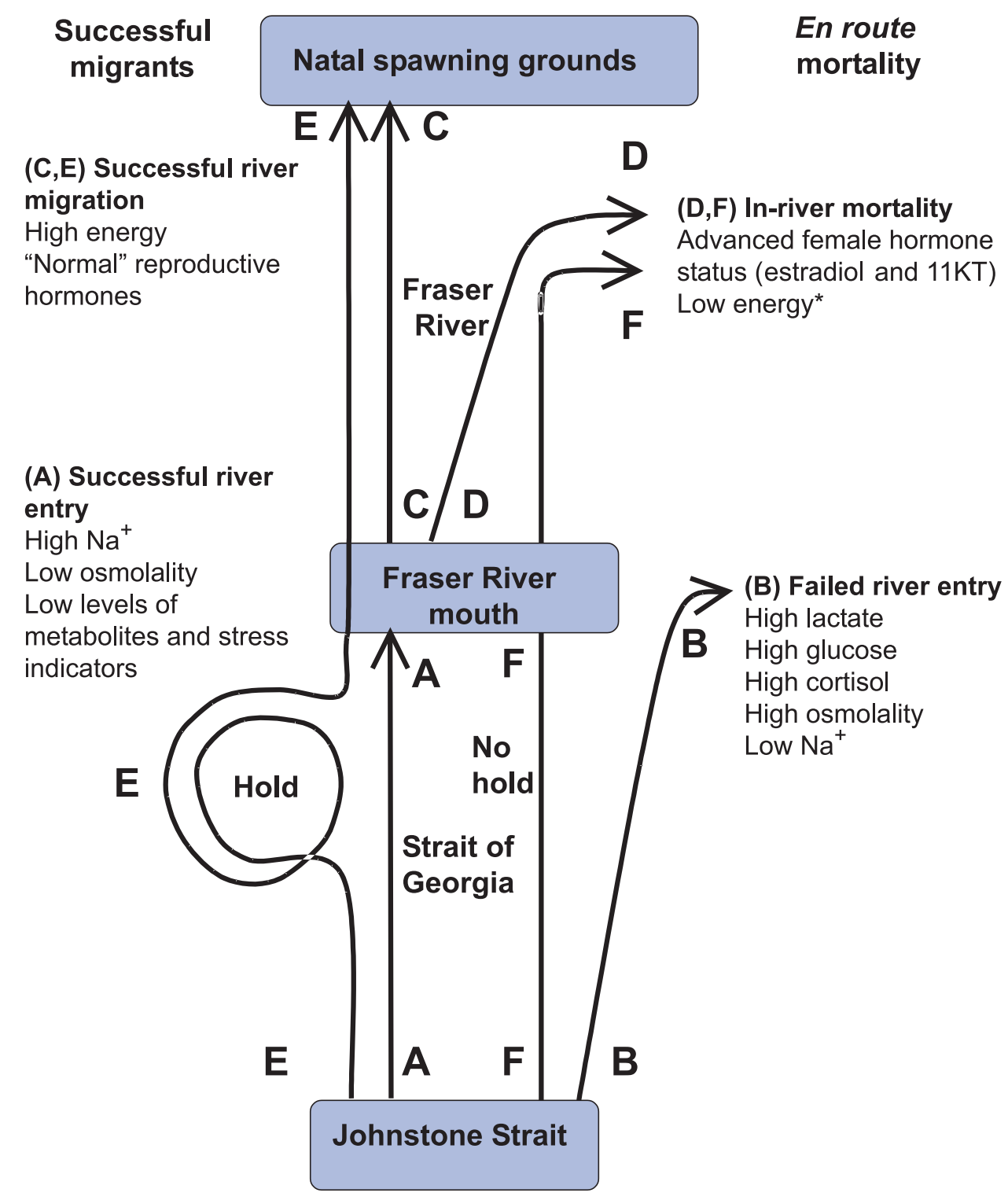

that held prior to migrating and were successful migrants compared with those that did not hold and died en route. Also, females that did not hold and died en route tended to have elevated levels of reproductive hormone titres (both $17 \beta$-estradiol and 11-ketotestosterone) relative to fish that had held in the Strait of Georgia and which successfully reached the spawning grounds. Perhaps if we had sampled the leading edge of the late-run migration (i.e., the first $32 \%$ of fish), where mortality rates were presumed to be even higher (e.g., Cooke et al. 2004b) and the contrast between the length of the holding period was even more extreme, these and other physiological and energetics variables may have exhibited more sharply defined differences.

\section{Conceptual model for early migration - high mortality}

The work presented here is not the only attempt to evaluate the physiological and energetic correlates of migration success for sockeye salmon in the Fraser River (e.g., Cooke et al. 2006), but it is the first to focus on the late-run sockeye salmon in an attempt to develop an integrated physiological and energetic understanding, in a migratory stage-specific manner, of the early migration - high mortality phenome- 
non. During the river entry phase, physiological stress (as measured by cortisol and anaerobic metabolites) affects migration success in late-run and summer-run (Cooke et al. 2006) sockeye. Gross somatic energy was relatively high in summer- and late-run salmon that failed to enter fresh water. During the river migration phase, both summer- and late-run fish that failed to reach spawning grounds exhibited advanced reproductive development, potentially indicative of early senescence. For the river migration phase, failed late-run Adams migrants had lower gross somatic energy, but the same pattern was not observed for the $\mathrm{W}-\mathrm{H}$ migrants. Collectively, these results suggest that in a given year, the physiological and energetic characteristics of sockeye salmon migrating through Johnstone Strait may be predictive of their fate, irrespective of run-timing group. Cooke et al. (2006) did note higher interstock variation in summer-run fish than we did for late-run fish, suggesting that fish exhibit physiological and energetic diversity at both the individual and the stock level, but that variation is not consistent among run-timing groups or stocks.

Our conceptual model is illustrated in a schematic diagram (Fig. 3) to summarize and illustrate the physiological and energetic characteristics associated with behaviour and fate of late-run sockeye migrants. The factors that contribute to mortality appear to vary with different migratory phases for late-run sockeye salmon. Of particular interest is the contrast between fish that held and survived and those that did not hold and died. As fisheries managers seek predictive tools to determine if and when sockeye will enter early and die en route, physiological tools may be able to provide some insight. If physiological assays could be conducted in near-real time, the predictive value of these tools would be increased. Future studies of this nature should attempt to increase sample size in an effort to increase statistical power (i.e., reduce potential for making a type II error), since we documented substantial interindividual variation (Peterman 1990). Furthermore, attempts need to be made to conduct the same type of research both further from the coastal environment and in the lower river. Indeed, the best predictor may in fact not be apparent when and where we sampled fish. Some variables may have greater predictive power either earlier or later in the migration. Indeed, Hinch et al. (2005) and Shrimpton et al. (2005) report that some physiological variables (e.g., gill $\mathrm{Na}^{+} / \mathrm{K}^{+}$ATPase) have already changed in the ocean, in preparation for spawning, at least $500 \mathrm{~km}$ from the river mouth. Even though attempts to use physiological data for predictive fisheries management is still some way off, there are already examples of where this is being tested for other species and having reasonable success (e.g., Aarestrup et al. 2000; Nielsen et al. 2004). The current study has revealed physiological differences contributing to the en route mortality of late-run sockeye salmon, providing fisheries managers with some insight into possible mechanisms. However, the ultimate causal factor for mortality may be more related to the reason why some fish are no longer holding (Cooke et al. 2004b) and why fish are in different physiological and energetic states. For now, the answers to those difficult questions continue to elude researchers and continue to place these valuable fisheries resources at risk. To address those questions may require focusing efforts on sockeye salmon earlier in their migration when they are still in the high seas environment and later in their migration when they have entered fresh water (e.g., Young et al. 2006). Technological innovations in biotelemetry (Cooke et al. 2004a) and the greater coupling of behaviour and physiology should yield additional tools for assessing the migration biology of free-swimming fish and for understanding this fisheries and conservation crisis.

\section{Acknowledgements}

All procedures used in this study were developed with approvals and guidance from the Canadian Council on Animal Care administered by The University of British Columbia and Fisheries and Oceans Canada. We thank Al Cass, Laura Richards, Steve Macdonald, Jim Cave, Jim Woodey, Mike Lapointe, Carmen McConnell, and others from the Pacific Salmon Commission and Fisheries and Oceans Canada for facilitating this project. Tagging, biopsy, and data management support was provided by Richard Alexander, Jay Sitar, Trisha Watson, Louise Kuchel, Jayme Davidson, Jim Ferguson, Bill Koski, Nathan Blakley, and Cezary Sliwinski. Mike Healey was involved in early project development. We also thank the skippers and the crew of the Royal Mariner 1 and the Sunfisher. Physiological assays were conducted by Jayme Davidson, Janette Garries, Andrea Lister, and Jeff Young. Genetic analyses were conducted by the Molecular Genetics Laboratory of the Pacific Biological Station under the direction of Terry Beacham. Funding for the telemetry component of the study was provided by a contract to LGL Limited from Fisheries and Oceans Canada. The biosampling component of the project was funded by a Natural Sciences and Engineering Research Council of Canada (NSERC) Strategic Grant, NSERC discovery grants, and the DFO Fraser River E-Watch Program. The lead author was supported by NSERC and Izaak Walton Killam postdoctoral fellowships.

\section{References}

Aarestrup, K., Nielsen, C., and Madsen, S.S. 2000. Relationship between gill $\mathrm{Na}^{+}, \mathrm{K}^{+}$-ATPase activity and downstream movement in domesticated and first-generation offspring of wild anadromous brown trout (Salmo trutta). Can. J. Fish. Aquat. Sci. 57: 2086-2095.

Barton, B.A. 2002. Stress in fishes: a diversity of responses with particular reference to changes in circulating corticosteroids. Integr. Comp. Biol. 42: 517-525.

Barton, B.A., and Schreck, C.B. 1987. Metabolic cost of acute physical stress in juvenile steelhead. Trans. Am. Fish. Soc. 116: 257-263.

Barton, B.A., Morgan, J.D., and Vijayan, M.M. 2002. Physiological and condition-related indicators of environmental stress in fish. In Biological indicators of stress in fish. Edited by S.M. Adams. American Fisheries Society, Bethesda, Md. pp. 111-148.

Beacham, T.D., Withler, R.E., and Wood, C.C. 1995. Stock identification of sockeye salmon by means of minisatellite DNA variation. N. Am. J. Fish. Manag. 15: 249-265.

Beacham, T.D., Lapointe, M., Candy, J.R., McIntosh, B., MacConnachie, C., Tabata, A., Kaukinen, K., Deng, L., Miller, K.M., and Withler, R.E. 2004. Stock identification of Fraser River sockeye salmon (Oncorhynchus nerka) using microsatellites and major histocompatibility complex variation. Trans. Am. Fish. Soc. 133: 1106-1126. 
Brett, R. 1995. Energetics. In Physiological ecology of Pacific salmon. Edited by C. Groot, L. Margolis, and W.C. Clarke. University of British Columbia Press, Vancouver, B.C. pp. 1-68.

Cabin, R.J., and Mitchell, R.J. 2000. To Bonferroni or not to Bonferroni: when and how are the questions. Bull. Ecol. Soc. Am. 81: 246-248.

Carruth, L.L., Dores, R.M., Maldonado, T.A., Norris, D.O., Ruth, T., and Jones, R.E. 2000. Elevation of plasma cortisol during the spawning migration of landlocked kokanee salmon (Oncorhynchus nerka kennerlyi). Comp. Biochem. Physiol. C, 127: 123-131.

Carruth, L.L., Jones, R.E., and Norris, D.O. 2002. Cortisol and Pacific salmon: a new look at the role of stress hormones in olfaction and home-stream migration. Integr. Comp. Biol. 42: 574-581.

Clarke, W.C., and Hirano, T. 1995. Osmoregulation. In Physiological ecology of Pacific salmon. Edited by C. Groot, L. Margolis, and W.C. Clarke. University of British Columbia Press, Vancouver, B.C. pp. 317-378.

Cooke, S.J., Hinch, S.G., Wikelski, M., Andrews, R.D., Wolcott, T.G., and Butler, P.J. 2004a. Biotelemetry: a mechanistic approach to ecology. Trends Ecol. Evol. 19: 334-343.

Cooke, S.J., Hinch, S.G., Farrell, A.P., Lapointe, M., Healey, M., Patterson, D., Macdonald, S., Jones, S., and Van Der Kraak, G. $2004 b$. Early-migration and abnormal mortality of late-run sockeye salmon in the Fraser River, British Columbia. Fisheries, 29(2): 22-33.

Cooke, S.J., Crossin, G.T., Patterson, D.A., English, K.K., Hinch, S.G., Young, J.L., Alexander, R.F., Healey, M.C., Van Der Kraak, G., and Farrell, A.P. 2005. Coupling non-invasive physiological assessments with telemetry to understand inter-individual variation in behaviour and survivorship of sockeye salmon: development and validation of a technique. J. Fish. Biol. 67: 1342-1358.

Cooke, S.J., Hinch, S.G., Crossin, G.T., Patterson, D.A., English, K.K., Healey, M.C., Shrimpton, J.M., Van Der Kraak, G., and Farrell, A.P. 2006. Mechanistic basis of individual mortality in Pacific salmon during spawning migrations. Ecology, 87.

Crossin, G.T., and Hinch, S.G. 2005. A non-lethal method for assessing the somatic energy content of freely migrating adult $\mathrm{Pa}-$ cific salmon. Trans. Am. Fish. Soc. 134: 184-191.

Crossin, G.T., Hinch, S.G., Farrell, A.P., Higgs, D.A., Lotto, A.G., Oakes, J.D., and Healey, M.C. 2004. Energetics and morphology of sockeye salmon: effects of upriver migratory distance and elevation. J. Fish Biol. 65: 788-810.

Dingle, H. 1980. Ecology and evolution of migration. In Animal migration, orientation, and navigation. Edited by S.A. Gauthreaux, Jr. Academic Press, New York. pp. 1-101.

English, K., Sliwinski, C., Labelle, M., Koski, W.R., Alexander, R., Cass, A., and Woodey, J. 2004. Migration timing and in-river survival of late-run Fraser River sockeye using radio-telemetry techniques. Report prepared by LGL Limited, Sidney, B.C., for the Pacific Biological Station of Fisheries and Oceans Canada.

Farrell, A.P., Gallaugher, P., Clarke, C., DeLury, N., Kreiberg, H., Parkhouse, W., and Routledge, R. 2000. Physiological status of coho salmon (Oncorhynchus kisutch) captured in commercial nonretention fisheries. Can. J. Fish. Aquat. Sci. 57: 1668-1678.

Farrell, A.P., Gallaugher, P.E., Fraser, J., Pike, D., Bowering, P., Hadwin, A.K.M., Parkhouse, W., and Routledge, R. 2001. Successful recovery of the physiological status of coho salmon on board a commercial gillnet vessel by means of a newly designed revival box. Can. J. Fish. Aquat. Sci. 58: 1932-1946.

Gilhousen, P. 1990. Prespawning mortalities of sockeye salmon in the Fraser River system and possible causes. Int. Pac. Salmon Fish. Comm. Bull. 26.
Healey, M.C., Lake, R., and Hinch, S.G. 2003. Energy expenditures during reproduction by sockeye salmon (Oncorhynchus nerka). Behaviour, 140: 161-182.

Hedgepeth, J.B., Fuhriman, D., Cronkite, G.M.W., Xie, Y., and Mulligan, T.J. 2000. A tracking transducer for following fish movement in shallow water and at close range. Aquat. Living Resour. 13: 263-408.

Hendry, A.P., and Berg, O.K. 1999. Secondary sexual characters, energy use, senescence, and the cost of reproduction in sockeye salmon. Can. J. Zool. 77: 1663-1675.

Hinch, S.G., and Bratty, J. 2000. Effects of swim speed and activity pattern on success of adult sockeye salmon migration through an area of difficult passage. Trans. Am. Fish. Soc. 129: 598-606.

Hinch, S.G., and Rand, P.S. 1998. Swim speeds and energy use of river migrating adult sockeye salmon: role of local environment and fish characteristics. Can. J. Fish. Aquat. Sci. 55: 1821-1831.

Hinch, S.G., Cooke, S.J., Healey, M.C., and Farrell, A.P. 2005. Behavioural physiology of fish migrations: salmon as a model approach. In Behaviour and physiology of fish. Fish Physiology Series. Vol. 24. Edited by K.A. Sloman, R.W. Wilson, and S. Balshine. Academic Press, London. pp. 240-285.

Houston, A.H. 1990. Blood and circulation. In Methods for fish biology. Edited by C.B. Schreck and P.B. Moyle. American Fisheries Society, Bethesda, Md. pp. 273-334.

Killick, S.R. 1955. The chronological order of Fraser River sockeye salmon during migration, spawning and death. IPSFC Bull. VII. International Pacific Salmon Fisheries Commission, New Westminster, B.C.

Kinnison, M.T., Unwin, M.J., Hendry, A.P., and Quinn, T.P. 2001. Migratory costs and the evolution of egg size and number in introduced and indigenous salmon populations. Evolution, 55: 1656-1667.

Kinnison, M.T., Unwin, M.J., and Quinn, T.P. 2003. Migratory costs and contemporary evolution of reproductive allocation in male chinook salmon. J. Evol. Biol. 16: 1257-1269.

Kubokawa, K., Yoshioka, M., and Iwata, M. 2001. Sex-specific cortisol and sex steroids responses in stressed sockeye salmon during spawning period. Zool. Sci. 18: 947-954.

Lapointe, M.F., Cooke, S.J., Hinch, S.G., Farrell, A.P., Jones, S., Macdonald, S., Patterson, D., Healey, M.C., and Van Der Kraak, G. 2004. Late-run sockeye salmon in the Fraser River, British Columbia are experiencing early upstream migration and unusually high rates of mortality: what is going on? In Proceedings of the 2003 Georgia Basin/Puget Sound Research Conference, 31 March - 3 April 2003, Vancouver, B.C. Edited by T.W. Droscher and D.A. Fraser. Puget Sound Action Team, Olympia, Wash. pp. 1-14.

Lee, C.G., Farrell, A.P., Lotto, A.G., MacNutt, M.J., Hinch, S.G., and Healey, M.C. 2003. Effects of temperature on swimming performance and oxygen consumption in adult sockeye (Oncorhynchus nerka) and coho (O. kisutch) salmon stocks. J. Exp. Biol. 206: 3239-3251.

Leonard, J.B.K., Iwata, M., and Ueda, H. 2002. Seasonal changes of hormones and muscle enzymes in adult lacustrine masu (Onchorhynchus masou) and sockeye salmon (O. nerka). Fish Physiol. Biochem. 25: 153-163.

Lucas, M.C., and Baras, E. 2001. Migration of freshwater fishes. Blackwell Science Ltd., Oxford, UK.

Macdonald, J.S. (Editor). 2000. Mortality during the migration of Fraser River sockeye salmon (Oncorhynchus nerka): a study of the effect of ocean and river environmental conditions in 1997. Can. Tech. Rep. Fish. Aquat. Sci. 2315.

Macdonald, J.S., Foreman, M.G.G., Farrell, T.(A.P.), Williams, I.V., Grout, J., Cass, A., Woodey, J.C., Enzenhofer, H., Clarke, W.C., 
Houtman, R., Donaldson, E.M., and Barnes, D. 2000. The influence of extreme water temperatures on migrating Fraser River sockeye salmon during the 1998 spawning season. Can. Tech. Rep. Fish. Aquat. Sci. 2326.

McCormick, S.D. 1993. Methods for the nonlethal gill biopsy and measurements of $\mathrm{Na}^{+}, \mathrm{K}^{+}$-ATPase activity. Can. J. Fish. Aquat. Sci. 50: 656-658.

McGarigal, K., Cushman, S., and Stafford, S. 2000. Multivariate statistics for wildlife and ecology research. Springer-Verlag, New York.

McKeown, B.A. 1984. Fish migration. Croom Helm Publishers, London, UK.

McMaster, M., Munkittrick, K., and Van Der Kraak, G. 1992. Protocol for measuring circulating levels of gonadal sex steroids in fish. Can. Tech. Rep. Fish. Aquat. Sci. 1836.

Milligan, C.L. 1996. Metabolic recovery from exhaustive exercise in rainbow trout. Comp. Biochem. Physiol. A, 113: 51-60.

Mommsen, T.P., Vijayan, M.M., Moon, T.W. 1999. Cortisol in teleosts: dynamics, mechanisms of action, and metabolic regulation. Rev. Fish Biol. Fish. 9: 211-268.

Nielsen, C., Aarestrup, K., Nørum, U., and Madsen, S.S. 2004. Future migratory behaviour predicted from premigratory levels of gill $\mathrm{Na}^{+} / \mathrm{K}^{+}$-ATPase activity in individual wild brown trout (Salmo trutta). J. Exp. Biol. 207: 527-533.

Patterson, D.A., Macdonald, J.S., Hinch, S.G., Healey, M.C., and Farrell, A.P. 2004. The effect of exercise and captivity on energy partitioning, reproductive maturation and fertilization success in adult sockeye salmon. J. Fish. Biol. 64: 1039-1059.

Peterman, R.M. 1990. Statistical power analysis can improve fisheries research and management. Can. J. Fish. Aquat. Sci. 47: 215.

Rand, P.S., and Hinch, S.G. 1998. Swim speeds and energy use of upriver-migrating sockeye salmon (Oncorhynchus nerka): simulating metabolic power and assessing risk of energy depletion. Can. J. Fish. Aquat. Sci. 55: 1832-1841.

Robertson, O.H. 1961. Relation of gonadal maturation to length of life in Pacific salmon. FASEB J. Fed. Proc. 20: 29-30.
Robertson, O.H., Wexler, B.C., and Miller, B.F. 1961. Degenerative changes in the cardiovascular system of the spawning Pacific salmon (Oncorhynchus tshawytscha). Circ. Res. 9: 826-834.

Schreck, C.B., Contreras-Sanchez, W., and Fitzpatrick, M.S. 2001. Effects of stress on fish reproduction, gamete quality, and progeny. Aquaculture, 197: 3-24.

Shrimpton, J.M., Patterson, D.A., Richards, J.G., Cooke, S.J., Schulte, P.M., Hinch, S.G., and Farrell, A.P. 2005. Ionoregulatory changes in different populations of maturing sockeye salmon (Oncorhynchus nerka) during ocean and river migration. J. Exp. Biol. 208: 4069-4078.

Thomas, L. 1997. Retrospective power analysis. Conserv. Biol. 11: 276-280.

Truscott, B., Idler, D.R., So, Y.P., and Walsh, J.M. 1986. Maturational steroids and gonadotropin in upstream migratory sockeye salmon. Gen. Comp. Endocrinol. 62: 99-110.

Wagner, G.N., Hinch, S.G., Kuchel, L.J., Lotto, A., Jones, S.R., Patterson, D.A., Macdonald, J.S., Van Der Kraak, G., Shrimpton, M., English, K.K., Larsson, S., Cooke, S.J., Healey, M.C., and Farrell, A.P. 2005. Metabolic rates and swimming performance of adult Fraser River sockeye salmon (Oncorhynchus nerka) after a controlled infection with Parvicapsula minibicornis. Can. J. Fish. Aquat. Sci. 62: 2124-2133.

Wood, C.M., Turner, J.D., and Graham, M.S. 1983. Why do fish die after severe exercise? J. Fish Biol. 22: 189-201.

Woodey, J.C. 1987. In-season management of Fraser River sockeye salmon (Oncorhynchus nerka): meeting multiple objectives. In Sockeye salmon (Oncorhynchus nerka) population biology and future management. Edited by H.D. Smith, L. Margolis, and C.C. Wood. Can. Spec. Publ. Fish. Aquat. Sci. 96: 367-374.

Young, J.L., Hinch, S.G., Cooke, S.J., Crossin, G.T., Patterson, D.A., Farrell, A.P., Van Der Kraak, G., Lotto, A.G., Lister, A., Healey, M.C., and English, K.K. 2006. Physiological and energetic correlates of en route mortality for abnormally early migrating adult sockeye salmon (Oncorhynchus nerka) in the Thompson River, British Columbia. Can. J. Fish. Aquat. Sci. 63: 1067-1077.

Zar, J.H. 1996. Biostatistical analysis. 3rd ed. Prentice Hall, Upper Saddle River, N.J. 